\title{
Corporate Governance Perception Index, Profitability and Firm Value in Indonesia
}

\author{
Mariana $^{1 *}$, Syukriy Abdullah², Muhammad Mahmud ${ }^{1}$ \\ ${ }^{1}$ Faculty of Islamic Economic Law, Al-Hilal College of Sharia Science Sigli, Aceh, Indonesia \\ ${ }^{2}$ Faculty of Economics and Business, Syiah Kuala University, Aceh, Indonesia \\ Email: ^marianamer02@gmail.com, syukriyabdullah@unsyiah.ac.id,muhamza59@gmail.com
}

How to cite this paper: Mariana, Abdullah, S., \& Mahmud, M. (2020). Corporate Governance Perception Index, Profitability and Firm Value in Indonesia. Technology and Investment, 11, 13-21. https://doi.org/10.4236/ti.2020.112002

Received: April 10, 2020

Accepted: May 26, 2020

Published: May 29, 2020

Copyright $\odot 2020$ by author(s) and Scientific Research Publishing Inc. This work is licensed under the Creative Commons Attribution International License (CC BY 4.0).

http://creativecommons.org/licenses/by/4.0/

\begin{abstract}
This research aims to find out the impact of the Corporate Governance Perception Index and profitability to firm value. The population is a company on the Indonesian Stock exchange and which follows the CGPI assessment in 2011-2015 and is found in 28 samples, the analysis of data using multiple linear regression. The results indicated that the Corporate Governance Perception Index and profitability simultaneously affected the firm value according to the Indonesia Stock Exchange. Besides, the Corporate Governance Perception Index, and profitability also partially and significantly affected firm value according to the Indonesia Stock Exchange.
\end{abstract}

\section{Keywords}

Corporate Governance Perception Index, Profitability, Firm Value

\section{Introduction}

The issue of good corporate governance is pulled back after several cases occurred in Indonesia, among others, the Bank Century case the loser clearing in 2008, which resulted in a deficit, funds Burglary Case Citibank is an internal bank until the case Help Bank Indonesia Liquidity (BLBI), which is the Bank Indonesia loan scheme to the bank that is experiencing liquidity problems during the monetary crisis in 1998. This scheme is based on an agreement between Indonesia and the International Monetary Fund (IMF) to overcome the crisis, Bank Indonesia recorded BLBI distribute Rp 147.7 trillion to the banks until December 48, 1998. This case shows that the still weak enterprise management system, or not maximal GCG (Good Corporate Governance). GCG is a guideline for managers to manage the company as a best practice by involving stakeholders in decision-making. GCG is a concept put forward to address the agency 
problem. GCG serves to foster investor confidence in the company (Emirzon, 2006).

Investor perceptions on the level of success of the company are reflected through the company's value. Increasing firm value because of the high price of stocks will make the market believe in the company's performance and prospects for the future. Improving corporate profits and maximize firm value is an enterprise interrelated objective to improve the welfare of shareholders so that these objectives will be an important criterion for maintaining the viability of the company. The increasing firm value may be able to satisfy the customer service, to give comfort to investors to invest in the company. However, to determine whether there is an increase in firm value in the eyes of investors and the public it can be seen from the cash flow of the company (Penman, 2001). Determination of the company's value varies on a company's ability to generalize in the prospective cash flows, except in unusual circumstances in which the net assets are liquidated has a value greater than the cash flow.

Each company has short-term and long-term objectives in which the company must maintain its firm value, the company carries out a short-term goal to earn a profit while its long-term goal is to maximize the firm value. Firm value can reflect from its stock price which shows the higher the share price of the company then the higher firm value to be acquired (Wiagustini, 2010). The value of the company not only reflects how intrinsic value at this time but also reflects prospects and hopes for the company's ability to increase its value in the future. Globalization has created a business environment that causes the need to review the management system used by the company to be able to survive and perspective so that the company is required to always increase the value of its company (Wedayanthi \& Darmayanti, 2016). The company's value can be affected by several factors, this paper will only discuss two factors, namely the Corporate Governance Perception Index (CGPI) and profitability. The first factor affecting firm value is CGPI (Randy, 2011; Retno \& Priantinah, 2012). This is due to their consideration of CGPI assessment information by investors, which means there is a more economic value that can be generated from the acquisition of Indonesia ranks the Most Trusted Company CGPI. In Indonesia in the effort to improve GCG, has been conducted the assessment of the Corporate Governance index annually conducted by The Indonesian Institute for Corporate governance (IICG). The main activities undertaken are researching GCG implementation conducted by the company, which then the result is poured in a report called Corporate Governance Perception Index (CGPI). Implementation of the principles of CGPI if implemented properly, then the activities of the company can run effectively and efficiently and will impact on the achievement of profit.

The second factor affecting firm value is profitability (Dewi \& Wirajaya, 2013; Fibriyanto, 2015; Rudangga \& Sudiarta, 2016; Setiadewi \& Purbawangsa, 2015). Improving corporate profits and maximize firm value is an enterprise interrelated objective to improve the welfare of shareholders so that these objectives will be an important criterion for maintaining the continuity of the company. 
The probability of companies with high profits tends to use more loans to obtain tax benefits. Profitability is the ratio of management effectiveness based on the results of returns generated from sales and investments that measure how much the company's ability to generate profits (Harahap, 2009), one of which can be seen through return on asset. Return on assets affects the value of the company (Wedayanthi \& Darmayanti, 2016).

This type of research is associative causal using the Multiple Linear Regression (MLR) method. Besides, the research period also uses the latest data from 2011 up to 2015, with the company's research population listed on the stock exchange and companies that follow the CGPI assessment. The reason for elections in the year is 2016 to 2019 companies that follow the assessment of CGPI become more sedimented. The purpose of this paper is to determine the nature and relationship between variables in a hypothesis test, namely to know the influence of Corporate governance Perception Index influence, and the profitability of together and partials on the firm value on the Indonesia Stock Exchange. This paper begins with a literature review covering the discussion of the firm value, CGPI, and profitability. Then, proceed with explaining the research method used, then this paper discusses the results of the research which includes statistical test results and hypotheses, conclusions and suggestions.

\section{Literature Review}

\subsection{Firm Value}

The firm value itself is the price received by prospective buyers who are paid by companies sold (Dewi \& Wirajaya, 2013). The Firm value is very important because a high corporate value will be attended by shareholder prosperity (Brigham dan Houston, 2012). Next according to Fama (1978), the firm value can be seen from its stock price. The stock price is formed on the demand and supply of investors so that the share price can be used as a proxy firm value. According to Jensen (2001), to maximize the firm value not only equity value is noted, but the financial resources such as debts and their preferred shares.

\subsection{Corporate Governance Perception Index (CGPI)}

Corporate Governance Perception Index (CGPI) is a ranking of GCG implementation in public companies listed on the JSE. The program is implemented since 2001 based on the idea of the importance of knowing the extent of public companies that have implemented corporate governance. Corporate Governance Perception Index ranking is organized in cooperation with SWA Magazine as media partners with the publication of a comparative study (benchmarking). Corporate Governance Perception Index has been followed by more than 60 public companies (listed companies), state, national and regional banks, and other private companies for the implementation of CGPI 2001 to 2011. The Corporate Governance Perception Index Participation is voluntary and involves the active participation of companies together with all stakeholders in a fulfilling 
phase of the program Corporate Governance Perception Index and it shows a shared commitment to promote good corporate governance (Indonesia, 2014).

\subsection{Profitability}

Profitability is a financial ratio that connects the elements of the balance sheet and profit and loss statement with one another can give an idea about the history of the company and its position on the current ratings. The size of the financial ratios used in this study is a profitability ratio that indicates the company's ability to generate income in a particular period (Dwi \& Syarfan, 2016). This ratio provides a measure of the effectiveness of the management of a company.

\subsection{Development of Research Framework and Hypotheses}

Corporate Governance Perception Index (CGPI) is a ranking company that generates a reliable corporate score that implements corporate Governance. The Rating sorts the company by top-ranked up to bottom. The higher the rating the company means the higher the Trust value level, it can be used as a positive signal for companies that can increase investor confidence to the company so that it will affect the value of securities Company. Results of reviews and comparisons will provide benefits to companies one of which is the CGPI can be used as indicators or quality standards to be achieved the company in the form of public recognition of the application of the principles of GCG. CGPI has no effect on firm value (Kebon \& Suryanawa, 2017). Another result found that GCG affected firm value (Randy, 2011; Retno \& Priantinah, 2012), obtaining the results of GCG affect firm value CG. Furthermore, Fitri and Herwiyanti (2015), obtaining the results of GCG does not affect firm value.

H1: The Corporate Governance Perception Index affects the firm value.

Profitability used by investors to analyze the company's performance against the performance of corporate profits, the better profitability of the emerging view of investors that the performance of both corporate profits and the company can use its assets to generate earnings. Investors see better corporate performance makes a lot of investors interested in shares of the company making the value of the stock rises. Research Wedayanthi and Darmayanti (2016), return on assets affects firm value. Return on assets is an important ratio that can be used to measure the ability of the company to make a profit with its assets (Andriyani, 2015). Profitability affects the indirect impact on firm value (Hermuningsih, 2012), the probability of an effect on firm value (Dewi \& Wirajaya, 2013; Fibriyanto, 2015; Rudangga \& Sudiarta, 2016; Setiadewi \& Purbawangsa, 2015).

$\mathrm{H} 2$ : Profitability affects firm value on the Indonesian Stock exchange.

\section{Methodology}

The population in this study are all companies listed on the Stock Exchange since 2011-2015 Indonesia. Furthermore, 28 samples obtained by the established criteria. This study uses an unbalanced panel data, where the number of units of 
time is different for each. Of the 28 samples were obtained 68 observational studies. The data used is data secondary data. Secondary data were obtained using online access http://www.idx.co.id/ by downloading all the published financial statements according to criteria predetermined sample, and the value obtained from the magazine self CGPI. The data analysis method used in this research is multiple linear regression analysis. Multiple linear regression analysis is used to predict how changes in the value of the dependent variable when the independent variable value increased or decreased in value (Firdaus, 2011; Mariana \& Abdullah, 2018), which is defined as follows

$$
Y_{i t}=a+\beta_{1} X_{1 i t}+\beta_{2} X_{2 i t}+e_{i t} .
$$

\section{Hypothesis Testing Design}

The F test is done to see how much impact all the independent Corporate Governance Perception Index variables are and the profitability of the dependent variables of the company value. The hypothesis testing plan is as follows:

$\checkmark$ If a significant value of F (F Value) is greater than 0.05 ( $\alpha>5 \%$ ), it can be inferred there is no influence over the entire variable independent of the dependent variable, then $\mathrm{H} 0$ received;

$\checkmark$ Conversely, if a significant value of F (F Value) is smaller than $0.05(\alpha<5 \%)$, it can be concluded that independent variables collectively affect the dependent variable, meaning $\mathrm{H} 0$ is rejected or Ha acceptable.

Partial hypothesis Testing plan (Test T), this test will prove $\mathrm{H} 0$ or $\mathrm{Ha}$ to be accepted. If $\mathrm{Ha}$ is accepted then $\mathrm{HO}$ is rejected. Hypothesis testing is used to know the relationship between the two variables there is a close or mutual relationship, between the free variables that are in the research in Corporate Governance Perception Index and profitability as well as variables tied to the company's value, then conducted a zero hypothesis test where T-test result decision can be seen in the coefficients table in column sig (significance). If the probability of a $\mathrm{T}$ value or significance is $<0.05$, then it can be said that there is a partial influence between the free variables to the bound variables. However, if the probability of a value of $\mathrm{T}$ or significance is $>0.05$, then it can be said that there is not a significant partial influence between each variable being free of bound variables.

\section{Results}

\subsection{Hypothesis Testing Results}

Hypothesis testing is done by multiple linear regression analysis. The results of multiple linear regression are presented in Table 1.

From the results presented in Table 1 can be constructed a regression equation as follows:

$$
Y_{i t}=-2.527+0.050 X_{1 i t}+0.030 X_{2 i t}+e_{i t} .
$$

A value $F$ value of 16.984 with a significance value of 0.000 means that the independent variables together affect the dependent variable because the significance 
Table 1. Results of multiple linear regression.

\begin{tabular}{ccccc}
\hline Variable & Coefficient & Std. Error & $t$ & Sig \\
\hline (Constant) & -2.527 & 1.131 & -2.234 & 0.029 \\
CGPI & 0.050 & 0.014 & 3.578 & 0.001 \\
Profitability (ROA) & 0.030 & 0.007 & 4.189 & 0.000 \\
F = 16.984 & & \multicolumn{2}{c}{ Sig $=0.000$} \\
R $=0.586$ & \multicolumn{2}{c}{ Adjusted $\mathrm{R}=0.323$} \\
\hline
\end{tabular}

Source: Research Data, Processing (2019).

value is less than $5 \%$ or 0.05 . This shows that the variable CGPI, and profitability, can be used to predict firm value on the Indonesian Stock Exchange. The value of the coefficient of determination shown in Table 1 of $0.343 \%$ or $34.3 \%$ means that the CGPI variable, profitability, and the size of the company can explain firm value amounted to $34.3 \%$. Ability to explain the independent variables was relatively small because of a larger percentage, namely $65.7 \%$, explained by other variables not included in this study.

A CGPI against the company's value in Table 1 shows the significance value for the CGPI variable of 0.001 with a size of $\mathrm{T}$ value of 3.578. The significance value is smaller than alpha $0.05(0.01<0.05)$. Thus, H01 was rejected and Hal was accepted, meaning that the CGPI was of significance to the value of the company on the Indonesian stock exchange. The value of the CGPI variable coefficient is 0.050 , indicating that if CGPI rises 1 (one) percent, it will result in an increase in the value of the company by 0.050 percent, assuming another variable is constant.

The impact of profitability on the company's value in Table 1 shows the significance value for the profitability variable at 0.000 with the size of the $\mathrm{T}$ value being 4.189. The significance value is smaller than alpha $0.05(0.000>0.05)$. Thus, $\mathrm{H} 02$ is rejected and $\mathrm{Ha} 2$ is accepted, which means that the profitability is influential significance to the value of the company on the Indonesian stock exchange. The value of the profitability variable coefficient is 0.030 , indicating that if profitability increased by 1 (one) percent, it would have resulted in a company's rise of 0.030 percent, assuming another constant variable.

\subsection{Discussion}

\subsubsection{CGPI Influence on Company Value}

CGPI significant effect on the firm value on the Indonesian Stock Exchange. This shows their consideration CGPI assessment information by investors, which means there is the more economic value that can be generated from the acquisition of Indonesia ranks the Most Trusted Company CGPI. According to IICG (https://iicg.org/wp/), rating CGPI sort of companies ranked by the top until the bottom. The higher the rating companies means that the higher the level of confidence, this can be used as a positive signal for the company to increase investor confidence in the company so that it would affect the value of securities companies. 
The results of this study supported the previously stated hypothesis of CGPI affecting the firm value. The results of the research CGPI no effect on firm value (Kebon \& Suryanawa, 2017). Another result found that GCG affected firm value (Randy, 2011; Retno \& Priantinah, 2012), obtaining the results of GCG affect firm value CG. Furthermore, Fitri and Herwiyanti (2015), obtaining the results of GCG does not affect firm value.

\subsubsection{Influence the Profitability of Firm Value}

Profitability affects the significance of the firm value in the Indonesia Stock Exchange. This demonstrates high profitability capable of reflecting the company's ability to generate high returns for shareholders. The greater the profit then the greater the ability of the company to pay dividends, and this has increased in the firm value. According to (Harahap 2009), the probability of companies with high profits tends to use more debt to obtain tax benefits. Profitability is the ratio of the effectiveness of management based on the returns generated from sales and investment, which measures how much a company's ability to generate profits. The results support the hypothesis stated earlier profitability affects firm value. Dewi and Wirajaya (2013); Fibriyanto (2015); Rudangga and Sudiarta (2016); Setiadewi and Purbawangsa (2015), who obtained the results of probability affect firm value. The results obtained from research inversely Chaidir (2014); Wedayanthi and Darmayanti (2016), profitability does not affect firm value. Furthermore, Hermuningsih (2012), obtaining profitability results have an indirect influence on firm value.

\subsection{Conclusion}

Based on the data analysis and hypothesis testing that has been done, it can be concluded that:

1) F value equal value 16.984 with a significance value of 0.000 means that the independent variables together affect the dependent variable because the significance value is less than $5 \%$ or $0.05 \%$. The coefficient of determination shown by $0.383 \%$ or $34.3 \%$ means that the variable CGPI, profitability, and the size of the company can explain firm value amounted to $34.3 \%$. Ability to explain the independent variables was relatively small because of a larger percentage, namely $65.7 \%$, explained by other variables not included in this study.

2) CGPI significant effect on the firm value on the Indonesian Stock Exchange. This shows their consideration CGPI assessment information by investors, which means there is the more economic value that can be generated from the acquisition of Indonesia ranks the Most Trusted Company CGPI.

3) Profitability affects the significance of the firm value in the Indonesia Stock Exchange. This demonstrates high profitability capable of reflecting the company's ability to generate high returns for shareholders.

\section{Conflicts of Interest}

The authors declare no conflicts of interest regarding the publication of this paper. 


\section{References}

Andriyani, I. (2015). Pengaruh Rasio Keuangan terhadap Pertumbuhan Laba pada Perusahaan Pertambangan yang Terdaftar di Bursa Efek Indonesia. Jurnal Manajemen Dan Bisnis Sriwijaya, 13, 343-358.

Brigham dan Houston (2012). Dasar-Dasar Manajemen Keuangan. Jakarta: Salemba Empat.

Chaidir (2014). Pengaruh Struktur Modal, Profitabilitas, dan Pertumbuhan Perusahaan terhadap Nilai Perusahaan pada Perusahaan Sub Sektor Transportasi Yang Tercacat di Bursa Efek Indonesia Periode 2012-2014. JIMFE, 1, 1-21. https://doi.org/10.34203/jimfe.v1i2.557

Dewi, A. S. M., \& Wirajaya, A. (2013). Pengaruh Struktur Modal, Profitabilitas dan Ukuran Perusahaan Pada Nilai Perusahaan. E-Jurnal Akuntansi Universitas Udayana, 2, 358-372.

Dwi, K., \& Syarfan, L. O. (2016). Analisis Laporan Keuangan Dalam Mengukur Kinerja Perusahan pada PT. Ricky Kurniawan Kerta Persada (Makin Group) Jambi. Valuta, 2, 190-207.

Emirzon, J. (2006). Regulatory Driven dalam Implementasi Prinsip-Prinsip Good Corporate Governance pada Perusahaan di Indonesia. Jurnal Manajemen \& Bisnis Sriwijaya, 4, 93-114.

Fama, E. F. (1978). The Effects of a Firm's Investment and Financing Decisions on the Welfare of Its Security Holders. American Economic Review and American Economic Association, 63, 272-284.

Fibriyanto, D. (2015). Analisis Pengaruh Struktur Modal terhadap Nilai Perusahaan Property dan Realestate Yang Listing Di Bursa Efek Indonesia Tahun 2009-2011. Jurnal Administrasi Bisnis, 27, 1-8.

Firdaus (2011). Ekonometrika: Suatu Pendekatan Aplikasi. Jakarta: Bumi Aksara.

Fitri, R. A., \& Herwiyanti, E. (2015). Pengaruh Corporate Social Responsibility dan Good Corporate Governance Terhadap Nilai Perusahaan. Journal \& Proceeding Fakultas Ekonomi \& Bisnis UNSOED, 5, 59-75.

Harahap, S. S. (2009). Analisis Kritis Laporan Keuangan. Jakarta: Raja Grafindo Persada.

Hermuningsih, S. (2012). Pengaruh Profitabilitas, Size terhadap Nilai Perusahaan dengan Sruktur Modal Sebagai Variabel Intervening. Jurnal Siasat Bisnis, 16, 232-242. https://doi.org/10.20885/jsb.vol16.iss2.art8

Indonesia, I. A. S. (2014). The Indonesia Corporate Governance Manual.

Jensen, M. C. (2001). Value Maximisation, Stakeholder Theory, and the Corporate Objective Function. European Financial Management, 7, 297-317. https://doi.org/10.1111/1468-036X.00158

Kebon, S. M. A. M., \& Suryanawa, I. K. (2017). Pengaruh Good Corporate Governance Dan Investment Opportunity Set Pada Nilai Perusahaan Di Bursa Efek Indonesia. E-Jurnal Akuntansi, 20, 1534-1563.

Mariana, N., \& Abdullah, S. (2018). Informasi Akuntansi, Informasi Non-Akuntansi, dan Keputusan Pemberian Kredit. Jurnal Reviu Akuntansi Dan Keuangan, 8, 177-186. https://doi.org/10.22219/jrak.v8i2.37

Penman, S. H. (2001). On Comparing Cash Flow and Accrual Accounting Models for Use in Equity Valuation. Contemporary Accounting Research (CAR), 18, 681-692. https://doi.org/10.1506/DT0R-JNEG-QL60-7CBP

Randy, V. (2011). Pengaruh Penerapan Good Corporate Governance terhadap Nilai Pe- 
rusahaan yang terdaftar di BEI 2007-2011. Business Accounting Review, 1, 306-318.

Retno, R. D., \& Priantinah, D. (2012). Pengaruh Good Corporate Governance dan Pengungkapan Corporate Social Responsibility terhadap Nilai Perusahaan (Studi Empiris pada Perusahaan Yang Terdaftar di Bursa Efek Indonesia Periode 2007-2010). Jurnal Nominal, 1, 84-103. https://doi.org/10.21831/nominal.v1i2.1000

Rudangga, I. G. N. G., \& Sudiarta, G. M. (2016). Pengaruh Ukuran Perusahaan, Leverage, dan Profitabilitas terhadap Nilai Perusahaan. E-Jurnal Manajemen Unud, 5, 4394-4422.

Setiadewi, K. A. Y., \& Purbawangsa, I. B. A. (2015). Pengaruh Ukuran Perusahaan dan Leverage terhadap Profitabilitas dan Nilai Perusahaan. E-Jurnal Manajemen Unud, 2, 596-609.

Wedayanthi, K. K., \& Darmayanti, N. P. A. (2016). Pengaruh Economic Value Added, Komposisi Dewan Komisaris Independen Dan Return On Assets terhadap Nilai Perusahaan. E-Jurnal Manajemen Unud, 5, 3647-3676.

Wiagustini, N. luh P. (2010). Dasar-Dasar Manajemen Keuangan. Denpasar: Udayana University Press. 